\title{
Crepuscular pollination and reproductive ecology of Trembleya laniflora (Melastomataceae), an endemic species in mountain rupestrian grasslands ${ }^{\text {is }}$
}

\author{
Natalia Costa Soares*, Leonor Patrícia Cerdeira Morellato \\ UNESP Univ Estadual Paulista, Instituto de Biociências, Departamento de Botânica, Laboratório de Fenologia, Rio Claro, São Paulo, Brazil
}

\section{A R T I C L E I N F O}

\section{Article history:}

Received 3 September 2016

Received in revised form 8 December 2016

Accepted 9 December 2016

Edited by Fernando A.O. Silveira

Available online 14 December 2016

\section{Keywords:}

Floral traits

Phenology

Buzz pollination

Reproductive system

Germination

Nocturnal bees

\begin{abstract}
A B S T R A C T
The "pollination syndrome" hypothesis predicts a direct relationship between a set of floral characters and the principal pollinating agent. The presence of flowers with poricidal anthers, heterostemony and pollen as the only reward are common traits in Melastomataceae species and are associated with buzz pollination by bees. Trembleya laniflora Cong. (Melastomataceae: Microlicieae) is an endemic species from campo rupestre tropical grassland, with large and white "pollen flowers" differing from the common purple-colored flowers of the Tribe. We examine the relationship between the distinct floral characteristics of $T$. laniflora and its pollination syndrome and reproduction ecology. We observed different individuals of $T$. laniflora randomly sampled in Serra do Cipó, Espinhaço Range, Minas Gerais, southeastern Brazil. We carried out observations on their reproductive phenology (31 individuals), flower biology (3), pollination (23), and tested the reproductive system (29). Trembleya laniflora presented a seasonal flowering pattern in the dry and post-dry seasons (May-October) and set fruits during the dry, post-dry and rainy seasons (June-December). Floral aperture occurred mainly during the night and the first hours of the morning, the period with the greatest availability of fresh flowers and with the highest visitation by Xylocopa bimaculata. Tests identified the species as non-apomictic, self-incompatible and dependent on large bees such as Xylocopa, Bombus, Centris and Ptiloglossa for pollination. Trembleya laniflora showed a specialized pollination system mediated by a restricted group of bees that perform crepuscular buzz pollination. Floral characteristics and reproductive biology of $T$. laniflora are likely adaptive responses to pollination by large bees foraging during the crepuscular hours. Our results support the "pollination syndrome" hypothesis, demonstrating a direct relationship between a set of floral characters and the principal pollinators of the species. Dependence on interbreeding may promote outcrossing within and among the endemic populations, naturally isolated on rocky outcrops.
\end{abstract}

(c) 2016 Elsevier GmbH. All rights reserved.

\section{Introduction}

The evolutionary relationship between pollinators and the floral traits of plant species is a topic historically described and discussed within plant biology (Darwin, 1862; Faegri and Van Der Pijl, 1979; Fenster et al., 2004; Ollerton et al., 2009; Rosas-Guerrero et al., 2014; Queiroz et al., 2015). The occurrence of the so-called "pollination syndromes" has been tested, and the idea of a direct relationship between a set of floral characters (e.g. coloration, form, size, timing of anthesis and type of resource offered) and the prin-

\footnotetext{
is This article is part of a special issue entitled Plant life in campo rupestre: new lessons from an ancient biodiversity hotspot published at the journal FLORA 238C.

* Corresponding author.

E-mail addresses: naturalcsoares@gmail.com, naturalcsoares@yahoo.com.br (N.C. Soares).
}

cipal pollinating agent generally persists (Faegri and Van Der Pijl, 1979; Rosas-Guerrero et al., 2014; but see Ollerton et al., 2009). This finding suggests that plants are adapted to a specific functional group of pollinators that exert selective pressure on floral traits (Fenster et al., 2004; Rosas-Guerrero et al., 2014). However, in cases where a species presents floral characteristics matching more than one syndrome or has a wide diversity of pollinators (generalist species), the plant-pollinator interaction may not be so obvious (Herrera, 1987; Herrera, 2005; Ollerton et al., 2009; Queiroz et al., 2015).

Within this evolutionary context, plant species that have pollen as a primary resource to reward pollinators present floral traits often related to the protection of pollen, the selection of pollinating agents, and the precise deposition of pollen on the body of the pollinator (Buchmann, 1983; Pinheiro et al., 2014). In these so-called "pollen flowers" (Vogel, 1978), the presence of poricidal anther dehiscence (tubular anthers with apical pores) is common and is 
associated with heterostemony (the occurrence of different types of stamens in the same flower) (Vogel, 1978; Buchmann, 1983; Pinheiro et al., 2014). These characteristics are generally interpreted as strategies for solving the "pollen dilemma", in which the pollen grain fulfills a dual function: transporting the male gamete and being the resource supply for the flower visitors (Westerkamp, 1996; Lunau et al., 2011, 2015). The pollination of these pollen flowers through buzz pollination is performed exclusively by bees with the capability to vibrate their abdomen and extract the pollen from the anthers, which generally present poricidal dehiscence (Buchmann, 1983; Pinheiro et al., 2014).

In general, bee pollination (melittophily) occurs during the day, in plants that present flowers with a diurnal aperture (Faegri and Van Der Pijl, 1979; Ollerton et al., 2009; Rosas-Guerrero et al., 2014). However, some species of Apidae, Andrenidae, Halictidae and Colletidae forage for floral resources (primarily pollen) in dim-light environments: at dawn, dusk and occasionally at night (Janzen, 1968; Wolda and Roubik, 1986; Wcislo et al., 2004). The knowledge of the biology of these "crepuscular bees", their ecological interactions and role as pollinators are limited, probably because their dim-light foraging habits are often restricted to crepuscular periods and eventual nocturnal flights in the presence of moonlight (Burgett and Sukumalanand, 2000; Hopkins et al., 2000; Somanathan and Borges, 2001; Wcislo et al., 2004; Franco and Gimenes, 2011).

In Melastomataceae, one of the most dominant and diverse families in the tropics (Clausing and Renner, 2001; Goldenberg et al., 2012), poricidal anther dehiscence and heterostemony are frequent traits; indeed, poricidal anthers are a diagnostic characteristic of the family and associated with buzz pollination (Buchmann, 1983; Renner, 1989). In Brazil, this family figures among the most speciesrich in the Atlantic forest, cerrado and campo rupestre (Giulietti et al., 1987; Mendonça et al., 2008). Neotropical bee species with vibratory capacity in Brazil belong to the families Apidae (e.g. Centridini, Bombini, Xylocopini, Meliponini), Halictidae (Augochlorini), Colletidae (e.g. Colletinae) and Andrenidae (Oxaeini) (Nunes-Silva et al., 2010).

Species of Trembleya (Melastomataceae), endemic to Brazil, present pollen flowers with poricidal anthers and heterostemony. The diplostemonous androecium is composed of distinct stamens arranged in two circles (antesepalous and antepetalous) (Martins, 1997). Ninety percent of the species of this genus are distributed in the campo rupestre of Minas Gerais (Martins, 1997) and are well represented in this heterogeneous vegetation dominating the Espinhaço Range above 900 m altitude (Conceição and Pirani, 2005, 2007; Rapini et al., 2008; Silveira et al., 2016). Trembleya laniflora Cong. (Melastomataceae: Microlicieae) is a species endemic to the campo rupestre in the south of the Espinhaço range and presents floral characteristics that are rare in the family (Renner, 1989): large flowers of white coloration, which differs from the vibrant, often purple color pattern found in the Tribe. Purple-magenta flowers are common in species of Trembleya, while entirely white petals are described only for T. laniflora, T. debilis and T. hirsutissima (Martins, 1997).

The study of plant reproductive biology, when associated with phenology (Ollerton and Lack, 1992; Ollerton and Dafni, 2005), the reproductive system (Zapata and Arroyo, 1978; Santos et al., 2012), pollination ecology (Brito and Sazima, 2012), and seed dispersal (Levin et al., 2003) and germination (Rodrigues and Silveira, 2013), contributes to a better understanding of the ecology and evolution of natural populations (Pombal and Morellato, 2000; Silveira et al., 2015). Therefore, by integrating the above information, we aimed to understand the ecological and evolutionary importance of the distinct floral characters of Trembleya laniflora for its successful reproduction on the rocky outcrops of campo rupestre. More specifically, we sought to answer the following questions: i) Do the floral characteristics (size, color, and timing of aperture) of T. laniflora indicate a differential foraging behavior of its predicted pollinators (pollen flowers with diurnal buzz pollination by bees)? ii) Are the flower traits consistent with the "pollination syndrome" hypothesis of melittophily (senso Faegri and Van Der Pijl, 1979)? iii) Does T. laniflora depend on pollinators for reproduction and fruit set? We expect that the presence of large, white flowers of T. laniflora is an adaptive response to pollination by large crepuscular bees. We also expect that $T$. laniflora dependence on interbreeding contributes to increase outcrossing and maintain the diversity of this species, given its distribution restricted to campo rupestre rocky outcrops. We discuss the "pollination syndrome" hypothesis and the ecological and evolutionary importance of pollination by crepuscular bees.

\section{Material and methods}

\subsection{Study area}

The study was conducted from January 2014 to December 2015 in an area of campo rupestre, locally referred to as Quadrante 16 (Q16), situated at $1303 \mathrm{~m}$ altitude $\left(19^{\circ} 17^{\prime} 42.0^{\prime \prime} \mathrm{S} ; 43^{\circ} 35^{\prime} 31.2^{\prime \prime} \mathrm{W}\right)$ and within the environmental protection area of Morro da Pedreira (APA Morro da Pedreira) at Serra do Cipó (SC), south of the Espinhaço Range, Minas Gerais, southeastern Brazil (Rocha et al., 2016). The climate at the SC region is classified as Cwp type (Köppen, 1931)-mesothermal, with well-defined dry and wet seasons organized in four distinguishable periods: dry season (May to September); post-dry season (October); rainy season (November to January); and post-rainy season (February to April) (Madeira and Fernandes, 1999; Silveira et al., 2016). The average annual mean temperature and total precipitation are $21.2^{\circ} \mathrm{C}$ and $1622 \mathrm{~mm}$, respectively (Madeira and Fernandes, 1999). The vegetation of the study area is classified as campo rupestre sensu stricto (Silveira et al., 2016), growing on quartzitic and sandy soils, and is composed of a vegetation mosaic dominated by meadows (sandy, stone and wet grasslands dominated by Poaceae) and rocky outcrops associated with herbs, sub-shrubby and shrubby species mostly from the families Melastomataceae, Velloziaceae, Malpighiaceae and Euphorbiaceae (Giulietti et al., 1987; Silveira et al., 2016).

\subsection{Study species}

Trembleya laniflora Cong. (Melastomataceae) is a shrubby species endemic to the campo rupestre of Minas Gerais, with an occurrence restricted to rocky outcrops (Martins, 1997). Flowers of the species are pentamerous (frequently, individuals present some tetramerous and/or hexamerous flowers), large $(\geq 4.5 \mathrm{~cm})$, showy and white-colored, with some individuals presenting small pink spots on the petals (Fig. 1) (Martins, 1997). The diplostemonous androecium presents heterostemony, with 10 glabrous stamens that are distributed in antepetalous and antesepalous circles and are distinguished by the size and coloration of the thecae (Martins, 1997). The fruits are dry, capsular and dehiscent, with numerous (from 400 to 850 seeds per fruit; personal observation), diminute (up to $0.57 \mathrm{~mm}$ ) self-dispersed seeds (Martins, 1997).

We separated the two circular groups of stamens in the androecium according to their putative functions (Renner, 1989; Martins, 1997; Ollerton and Dafni, 2005): the stamens in the antepetalous circle (short, with yellow-colored thecae) are those responsible for the production of food pollen (hereafter feeding anthers); and the stamens in the antesepalous circle (long, with purple-colored thecae and presence of the connective) are those responsible for the production of pollen for pollination (hereafter pollination anthers) 

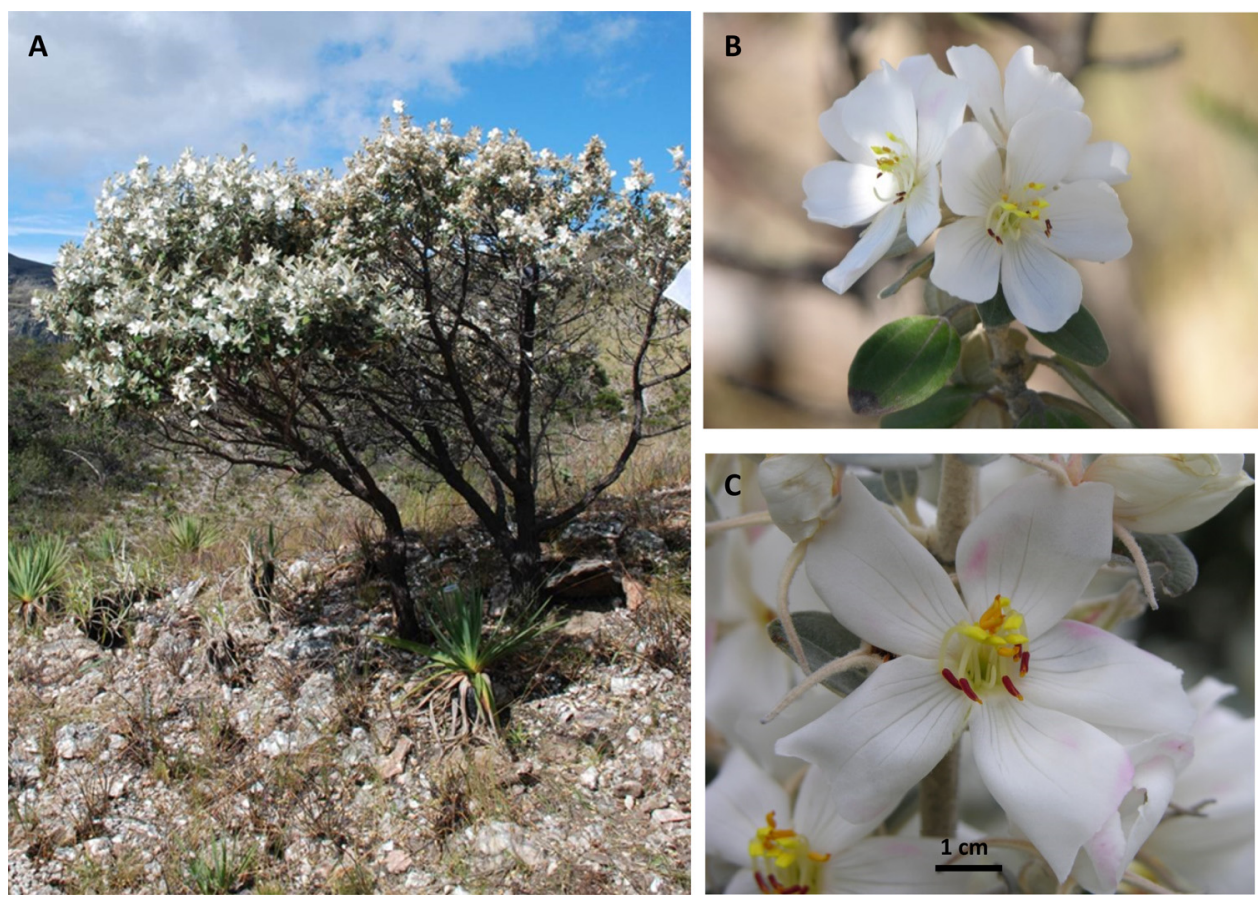

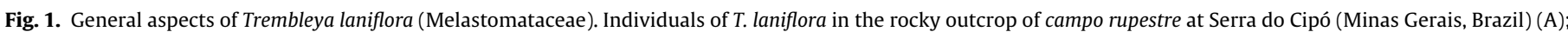
detail of the inflorescence (B); and a single flower with some pink spots (C).

(Fig. 1). Thus, we defined the occurrence of two types of pollen: one from the feeding anthers and the other from pollination anthers.

\subsection{Flower biology}

To study the floral biology (timing of opening and floral longevity), we tagged 40 pre-anthesis floral buds from three Trembleya laniflora individuals randomly chosen from throughout the area (Q16). The timing of flower opening and closing, as well as floral longevity, were determined by monitoring the tagged floral buds from the beginning of anthesis until the wilting and closing of the flowers. We observed the floral bud and flower development stages during four consecutive days, from dawn until dusk (05:30-18:30h), performing hourly surveys, except during the dawn $(05: 30-06: 30 \mathrm{~h})$, when the surveys occurred every $30 \mathrm{~min}$. On the fourth day of observation, we made only four surveys throughout the day (06:00 h; 07:00 h; 12:00 h and 18:20 h), since most flowers were already senescent. The stigmatic receptivity was tested immediately after flower opening, using hydrogen peroxide $\left(20 \% \mathrm{H}_{2} \mathrm{O}_{2}\right)$ on 22 fresh flowers randomly collected from individuals randomly chosen inside the study area (Dafni et al., 2005).

\subsubsection{Pollen viability}

To confirm the existence of two pollen types, we tested the viability of the pollen from the feeding and pollination anthers. Preanthesis floral buds from seven $T$. laniflora individuals were first isolated in organza mesh; after anthesis, 35 flowers were collected and fixed in a formaldehyde solution (FAA 80\%). From each flower, we extracted and separately macerated six anthers (three feeding and three pollination anthers). The obtained samples were diluted in ethyl alcohol (80\%), stained with acetic carmine (2\%) and analyzed in an electronic light microscope (40X objective) (Radford et al., 1974). We counted 214 pollen grains derived from feeding anthers and 231 from pollination anthers, and we quantified the number of viable (colored grains) and non-viable (not colored) pollen grains in each sample. To compare the viability of the pollen grains, we performed a two-sample proportion test.

\subsection{Phenology}

For the phenological monitoring, we randomly sampled and tagged 31 reproductive $T$. laniflora individuals from a $100 \mathrm{~m} \times 100 \mathrm{~m}$ (1 ha) plot inside the study area (Q16). Phenological observations were conducted monthly from January to December 2014; we counted the number of reproductive structures (floral buds, flowers, immature fruits and mature fruits) on five tagged branches of each individual (Ollerton and Dafni, 2005; Athayde and Morellato, 2014). During the flowering peak (July-August) of 2014, phenological observations were conducted every 15 days. Previous phenological observations carried out in 2012 and 2013 confirmed the annual flowering pattern of $T$. laniflora. However, due to fires in September 2014, we lost 15 out of 31 sampled individuals; therefore, the phenological observations from September to December 2014 refer to only 16 individuals.

\subsection{Reproductive systems}

To examine the reproductive system of $T$. laniflora and test the importance of the pollinators and both pollen types for reproduction, we performed controlled field tests of pollination on $29 \mathrm{~T}$. laniflora individuals randomly selected inside the study area (Q16) (Zapata and Arroyo, 1978; Dafni et al., 2005), as well as controlled lab tests of germination and presence/viability of embryos (Zapata and Arroyo, 1978). The controlled pollination tests checked for the occurrence of 1) cross-pollination (CP) - after anthesis of previously isolated buds on $20 \mathrm{~T}$. laniflora individuals, 146 flowers were emasculated and pollinated manually with pollen collected from nearby individuals. We pollinated 74 flowers with pollen from the pollination anthers (CP_poll) and 72 flowers with pollen from the feeding anthers (CPffeed); 2) self-pollination (SP) - after the anthesis of the bagged buds, 150 flowers of 12 individuals were emasculated and manually pollinated with their own pollen. We treated 77 flowers with pollen from pollination anthers (SP_poll) and 73 with pollen from the feeding anthers (SP_feed); 3) autonomous self-pollination $(A S)$ - on 10 individuals, we isolated 86 floral buds in small organza 
bags and monitored their phenology until the principal fruiting period; 4) apomixis (AP) - we emasculated 79 pre-anthesis floral buds from thirteen different individuals, isolated the emasculated buds with organza bags and monitored them until the fruiting period; 5) control ( $\mathrm{CN}$ ) - we monitored the reproductive phenology of 245 previously tagged floral buds on nine treated individuals. The fruits resulting from the various tests were collected, and the seeds from the 20 fruits in each treatment were counted and weighed on a precision balance (Model AR2140, $\mathrm{e}=1 \mathrm{mg}, \mathrm{d}=0.1 \mathrm{mg}$ ). To test for difference among the treatments, we quantified $i)$ the number of fruits formed; ii) the number of seeds formed per fruit ( $N=20$ fruits per treatment); and iii) the seed weight (total weight/number of seeds; $\mathrm{N}=20$ fruits per treatment).

The reproductive system was assessed based on the conversion rates (flower/fruit), the reproductive efficacy (RE), the selfincompatibility index (ISI) and the autonomous self-pollination index (IAS) (Zapata and Arroyo, 1978), and the presence and viability of the embryo after the germination experiments (Brasil, 2009). RE of each treatment was calculated by dividing the conversion rate (flower/fruit) of the treatment by the conversion rate of the control ( $\mathrm{SP} / \mathrm{CN}$ and $\mathrm{CP} / \mathrm{CN}$ ). RE values close to 0 indicate low reproductive efficacy, while values close or equal to 1 indicate high reproductive efficacy. ISI was calculated by dividing the conversion rates for the self-pollination treatments by those for the cross-pollination treatments $(\mathrm{SP} / \mathrm{CP})$. Self-compatibility is indicated by ISI = 1, incomplete self-compatibility by $0<\mathrm{ISI}<1$, and self-incompatibility by $I S I=0$. IAS was obtained through dividing the conversion rate of the autonomous self-pollination treatment by that of the control $(\mathrm{AS} / \mathrm{CN})$; an IAS value $=1$ indicates the occurrence of autonomous self-pollination, and IAS $=0$ indicates the absence of autonomous self-pollination (Zapata and Arroyo, 1978).

\subsubsection{Seed germination test}

All seeds produced by fruits following the cross-pollination, self-pollination and control tests were placed for germination in Petri dishes covered by filter paper moistened with distilled water, exposed to temperatures of $20-30^{\circ} \mathrm{C}$ and a 24 -h photoperiod (Rodrigues and Silveira, 2013). For each treatment (CP_poll, $C P$ feed, SP_poll, SP_feed, and control), we used six samples of 25 seeds, total 150 seeds per treatment. Autonomous self-pollination and apomixis treatments did not set fruit or viable seed (see Results).

We inspected the seeds every $48 \mathrm{~h}$, using radicle emergence (visible to the naked eye) as the criterion of germination (Labouriau, 1983). After a minimum of 30 days following initiation of the germination experiments, all non-germinated seeds were submitted to the tetrazolium test and examined for the presence and viability (coloration) of the embryo. We placed the seeds in a tetrazolium solution ( $1 \%$ ), conditioned to a temperature of $30^{\circ} \mathrm{C}$, for a minimum of $24 \mathrm{~h}$ (minimum time for coloration of tetrazolium solution); we then cut the seeds and observed them in a $4.5 \times$ magnifying glass loupe (Brasil, 2009).

\subsection{Pollination ecology}

The flower visitors and their foraging behavior (resource sought and time of visit) were observed in July and August 2014 ( $80 \mathrm{~h}$ of observation) and in July 2015 (43 h of observation). In 2014, we observed visitations to $23 \mathrm{~T}$. laniflora individuals that had been sampled for phenological observations and had blossomed during the flowering peak of the species (July and August). We randomly performed 10 -min surveys in each individual between $05.30 \mathrm{~h}$ and $18.30 \mathrm{~h}$ (dawn to dusk) each day (Herrera, 1995). In 2015, over four consecutive days, between $05.30 \mathrm{~h}$ and $18.30 \mathrm{~h}$, we made focal observations of four $T$. laniflora individuals chosen from the sample area (Q16) (Dafni et al., 2005). The dawn and dusk periods were defined taken into consideration of the short days during the dry season and sunrise after $06.00 \mathrm{~h}$.

In 2014, we aimed to assess the diversity of flower visitors and pollinators, mainly by observing the behavior of insects on the flowers (Herrera, 1995; Dafni et al., 2005). In 2015, however, we focused on identifying the flower visitors and the effective pollinators of T. laniflora, classifying the latter as principal or secondary according to their collection and foraging behavior, as well as assessing the frequency of visitation (Inouye et al., 1994; Rosas-Guerrero et al., 2014; Dafni et al., 2005). Among the effective pollinators, we considered as main pollinators the large bee species $(\geq 2.5 \mathrm{~cm})$ that were capable of vibrating both types of anthers concurrently and contacted the reproductive flower parts 10 times or more ( $\mathrm{N} \geq 10$ visits); we considered as secondary pollinators the large bees $(\geq 2.5 \mathrm{~cm}$ ) that possessed vibration capability and contacted the reproductive parts less than 10 times ( $\mathrm{N} \leq 10$ visits). Small bees $(\leq 1.5 \mathrm{~cm})$ that were not capable of vibrating both types of anthers concurrently, pollen robbers and other insects that visited the flowers but did not contact the stigma were considered flower visitors.

Specimens not identified in the field were collected and/or filmed with a SONY HDR-SR11 video camera and then deposited in the Entomological Collection of the Department of Zoology, IB, UNESP, campus of Rio Claro, SP. The data collected in 2014 (the year with the most hours of observation) were used to analyze visitation over time. The 2015 data from the focal observations were used only to compose a list of the $T$. laniflora flower visitors and effective pollinators (main and secondary), enabling the detection of less frequent and/or rare species (Dafni, 1992). Due to the morphological similarity of Eulaema nigrita and Bombus pauloensis (large bees considered here as effective pollinators) and the difficulty of distinguishing them in the field, we combined their data for the visitation analysis.

\subsection{Data analyses}

The reproductive phenology pattern of the species was tested through circular statistics (Morellato et al., 2000), using the data (dates of flowering and fruiting) obtained between January and December 2014. The Rayleigh ( $\mathrm{z}$ ) test which measures the significance of the average angle (Zar, 1996) was applied to detect the occurrence of a significant seasonal pattern in the phenophases (Morellato et al., 2000).

We applied a two-sample proportion test to compare the conversion rates (flower/fruit) between the controlled pollination experiments and each treatment as well as between the treatments. Differences between each treatment in the number of seeds produced per fruit were tested through the Kruskal-Wallis test, while differences in the weights of the seeds from fruits formed in the various treatments were tested through the ANOVA and a posterior Tukey test (Zar, 1996). We performed the circular analyses in Oriana 4 and the other analyses in the software $R$ version 3.1.3 ( $R$ Development Core Team, 2011).

\section{Results}

\subsection{Flower biology}

Trembleya laniflora presented a mainly nocturnal and/or crepuscular floral opening. Of the 40 tagged buds, 18 (45\%) opened during the night (between $18.30 \mathrm{~h}$ and $05.30 \mathrm{~h}$ ), and 13 (32.5\%) opened during sunrise (from $05.30 \mathrm{~h}$ to $06.30 \mathrm{~h}$ ). The majority of flowers $(90 \%)$ were available to pollinators in the first hours of the morning, and we did not observe floral opening during the afternoon (Fig. 2).

The flowers remained open for a minimum of two days. Of the 38 tagged flowers, 23 (60.5\%) remained open for three days, 10 


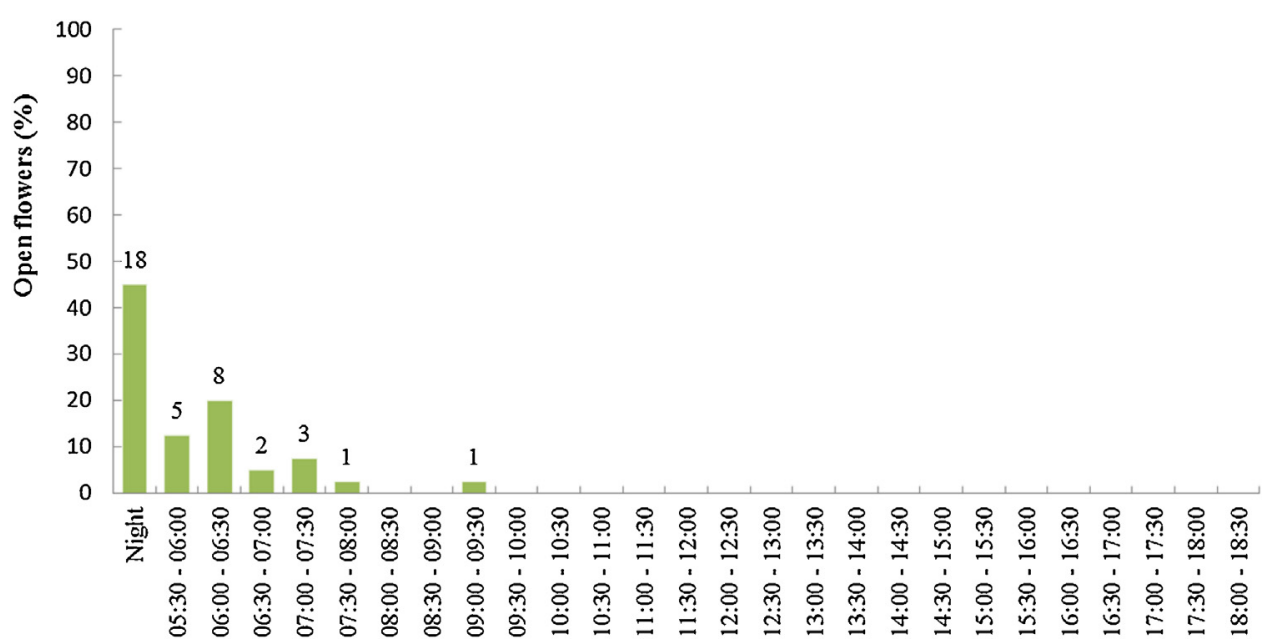

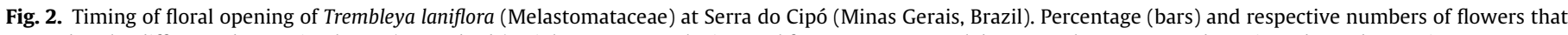
opened at the different observation hours ( $\mathrm{N}=40$ buds). Night represents the interval from 18:30 to 5:30 h between the present and previous days' observations.
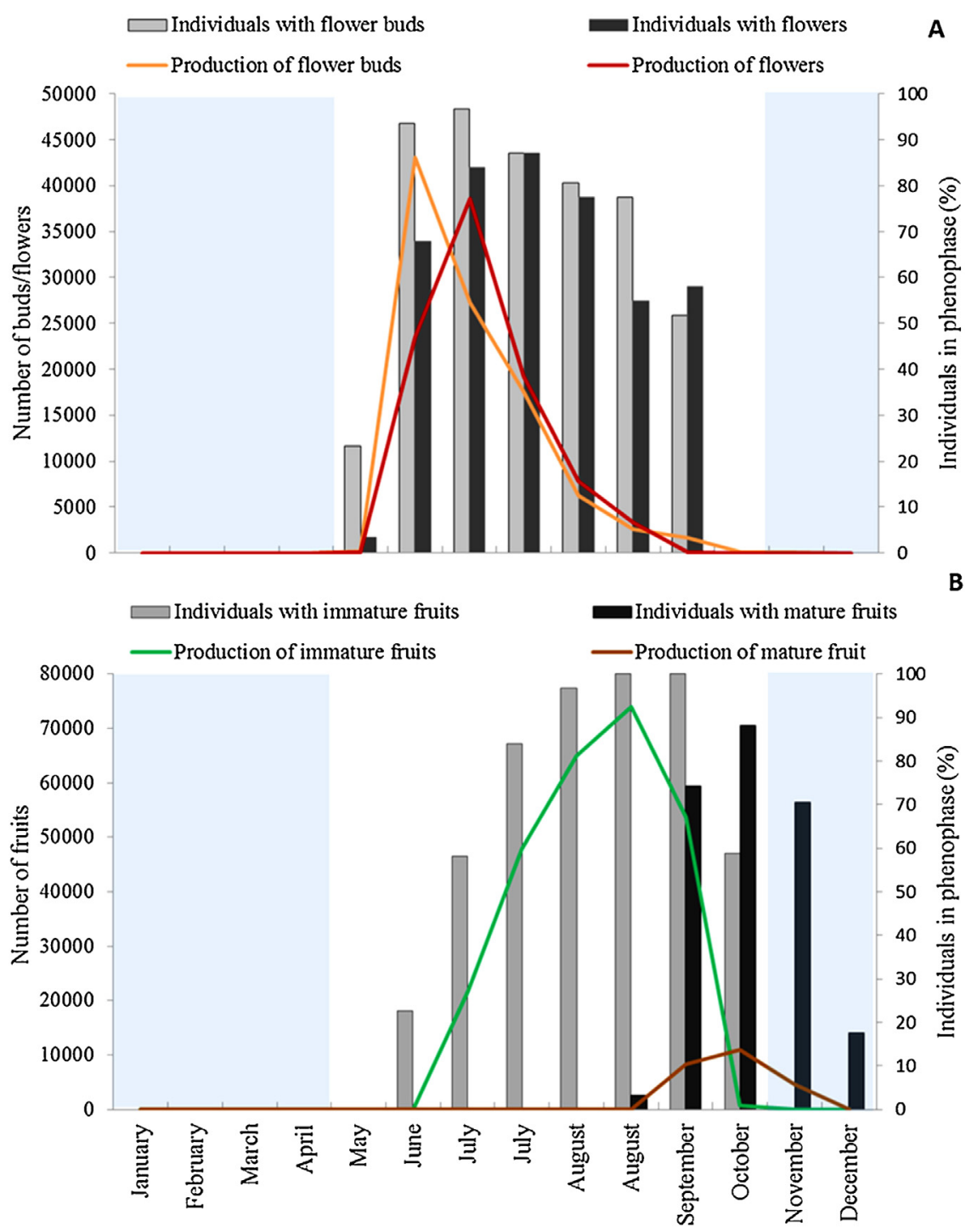

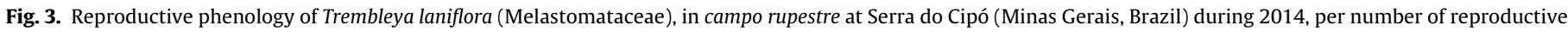

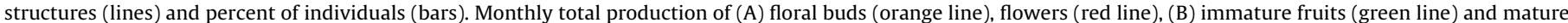

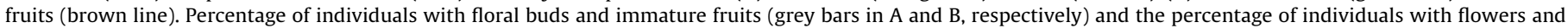

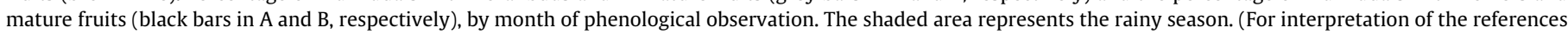
to colour in this figure legend, the reader is referred to the web version of this article.) 
Table 1

Results of reproductive system experiments Fruit set, Index of self-incompatibility (ISI), Index of autonomous self-incompatibility (IAS) and Reproductive efficacy (RE) of Trembleya laniflora (Melastomataceae), Serra do Cipó, Minas Gerais, Brazil. Parentheses indicate the number of treated buds; Fruit set = conversion rate flower/fruit; (Fruit/Flower) $=$ number of production fruits/number of flowers treated. Different letters indicate significant differences after two-sample tests $(p<0.05)$. ISI, IAS and $\mathrm{RE}$ range from 0 to 1 .

\begin{tabular}{llccc}
\hline Treatment & Fruit set & ISI & IAS & ER \\
\hline Control (245) & $0.71(173 / 245)^{\mathrm{a}}$ & & & \\
Cross pollination_pollination pollen (74) & $0.73(54 / 74)^{\mathrm{a}}$ & & & 1.00 \\
Cross pollination_feed pollen (72) & $0.68(49 / 72)^{\mathrm{a}}$ & & & 0.96 \\
Self pollination_pollination pollen (77) & $0.76(59 / 77)^{\mathrm{a}}$ & 1.00 & & 1.00 \\
Self pollination_feed pollen (73) & $0.74(54 / 73)^{\mathrm{a}}$ & 1.00 & & 1.00 \\
Autonomous self-pollination (86) & $0.00(0 / 86)^{\mathrm{b}}$ & & 0.0 & \\
Apomixis (79) & $0.03(2 / 79)^{\mathrm{b}}$ & & & 0.04 \\
\hline
\end{tabular}

flowers (26.5\%) for two days, and five flowers (13.2\%) for up to four days. The stigma was receptive from the beginning of the anthesis (19 receptive/22 tested). Pollen from both of the anthers presented high viability, with a proportion equal to $96 \%$ for the two types of pollen.

\subsection{Phenology}

Trembleya laniflora flowered during the dry and post-dry seasons (May-October) and fruited throughout the dry and post-dry seasons and the beginning of the rainy season (June-December) (Fig. 3). Flowering peaked during the dry season, in June (floral bud) and July (anthesis), while fruiting peaked at the end of the dry season (August; immature fruit) and post-dry season (October; mature fruit) (Fig. 3 and Table 1, supplementary material). Reproduction presented a significant and highly seasonal pattern $(r \geq 0.96$; Table 1, supplementary material). We observed the following maximum monthly productions (production peaks): 43,047 floral buds; 38,619 flowers; 73,888 immature fruits; and 10,000 mature fruits (Fig. 3).

\subsection{Reproductive system}

\subsubsection{Controlled pollination test}

Trembleya laniflora produced fruits and seeds in the crosspollination and self-pollination tests, independent of the pollen type (treatment), and showed high values of fruit set $(\geq 0.68)$ in both tests (Table 1). ISI values were equal to 1 in both of the induced self-pollination treatments, indicating compatibility independent of the pollen origin. The formation of fruits by apomixis was not significant (Fruit set ${ }_{A P}=0.03$ ), and we found no evidence of autonomous self-pollination (IAS $=0$ ). The production of fruits by cross-pollination and by induced self-pollination was effective (RE $>0.9$ ). Rates of flower/fruit conversion (fruit set) obtained for cross-pollination treatments did not differ from the rates for the self-pollination treatments (CP_Poll x SP_Poll, $\chi^{2}=0.1, p=0.74$ and CP_Feed $x$ SP_Feed $\left.\chi^{2}=0.3, p=0.54\right)$. We did not observe significant differences between the conversion rates for the treatments of each test (Table 1 ). We found significant differences when comparing the conversion rate between the control and the autonomous self-pollination and apomixis. Differences were also significant between CP and SP treatments with AS (Table 1).

Regarding seed production, we found significant differences between the number of seeds produced per fruit $(K=10.42, p=0.03$; Fig. 1, supplementary material) in the experiments (CP $x \mathrm{SP}$ ). Fruits resulting from the cross-pollination treatments (CP_Poll and CP_Feed) produced more seeds than those obtained from the selfpollination treatments (SP_Poll and SP_Feed) and from the control (CN) (see median values, Fig. 1, supplementary material). We found no significant differences in seed weight among treatments ( $\mathrm{F}=1.34, p=0.26$ ANOVA) (Fig. 2, supplementary material).

\subsubsection{Seed germination}

We observed germination in only nine seeds, all of which resulted from cross-pollination treatments with pollen from the feeding anthers (Fig. 4). T. laniflora seeds presented embryos only in the interbreeding experiments (CP_Feed and CP_Poll). However, we did not find viable stained embryos (colored) after immersion of

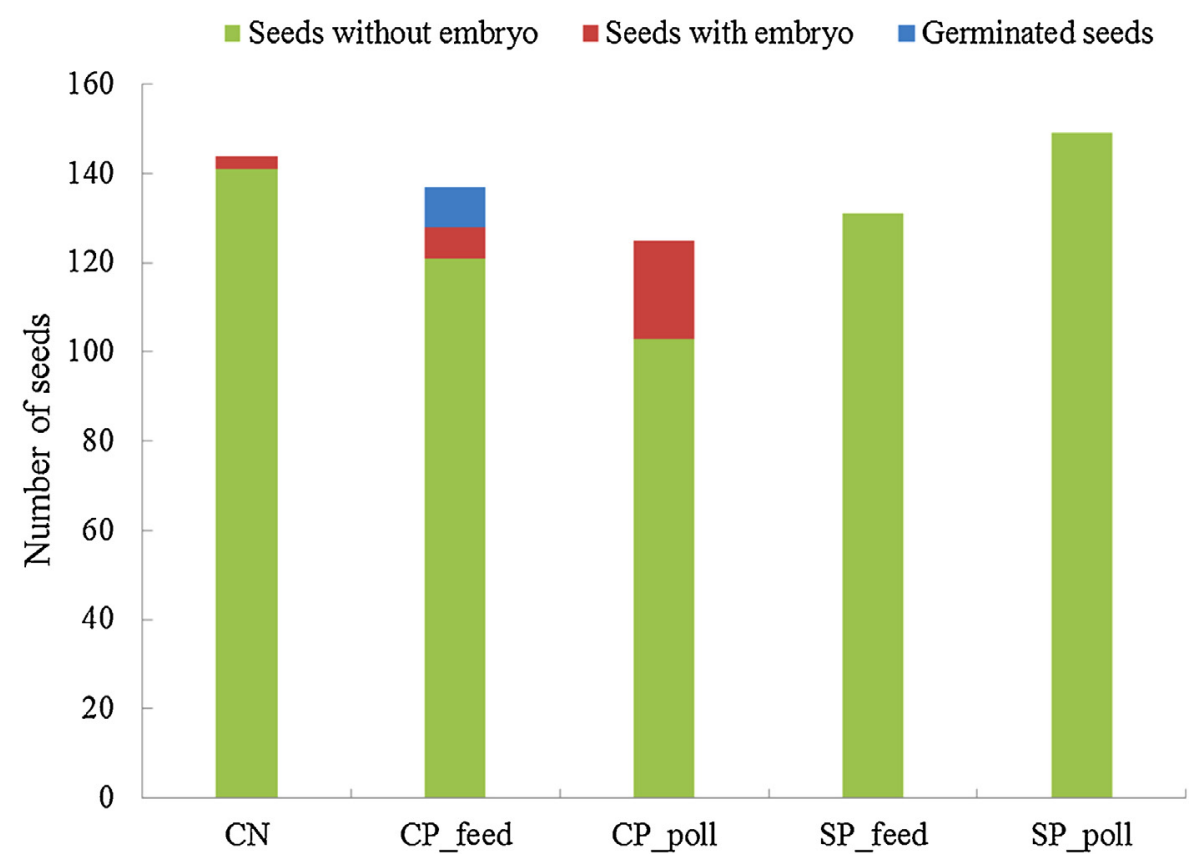

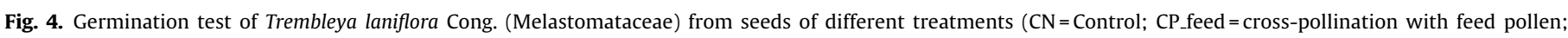
$\mathrm{CP}$ _poll $=$ cross-pollination with pollination pollen; SP_feed $=$ Self-pollination with feed pollen; SP_poll = Self-pollination with pollination pollen $)$. 
the seeds in the tetrazolium solution. For all treatments, we found a high proportion (69-99\%) of embryoless seeds (Fig. 4).

\subsection{Pollination ecology}

We observed 29 insect species visiting the T. laniflora flowers (Table 2, supplementary material), and bees were the most common flower visitors (Fig. 5; Table 2, supplementary material). Among the species found, 13 were considered as pollinators (three main and 10 secondary); the others included four flower visitors and 12 pollen robbers (Table 2 , supplementary material). We counted 254 visits to the T. laniflora flowers: 117 (46\%) by pollinators and the remaining 137 (54\%) by flower visitors. The pollination events occurred mainly during the short crepuscular periods (42\%) at dawn (from 06:00 h to 07:00 h) and dusk (from $17: 30 \mathrm{~h}$ to $18: 00 \mathrm{~h}$ ) and during the morning period (from $08: 00 \mathrm{~h}$ to $11: 00 \mathrm{~h})(40 \%)$, with peak pollination $(\mathrm{N}=24)$ occurring in the morning twilight between 06:00 $\mathrm{h}$ and 06:30 $\mathrm{h}$ (Fig. 5A). Flower visitor frequency was highest from 09:00 h to $14: 30 \mathrm{~h}(\mathrm{~N}=101)$, with peak activity from $10: 30 \mathrm{~h}$ to $11: 00 \mathrm{~h}(\mathrm{~N}=20)$. $T$. laniflora generally presented a low frequency of flower visitors during the day $(<10 \%$; Fig. 5B).

Among the main pollinators, Xylocopa (Dasyxylocopa) bimaculata was the most effective, contributing $34 \%(\mathrm{~N}=40)$ of all pollination events, followed by Xylocopa sp1, with 38 visits to the flowers (32\%) and Xylocopa sp4 with 12 visits (10\%). The other $14 \%$ of the visits were shared among Eulaema nigrita/Bombus pauloensis $(\mathrm{N}=15)$, Centris $\mathrm{sp} 1(\mathrm{~N}=5)$ and Oxaea $\mathrm{sp}(\mathrm{N}=4)$, all secondary pollinators (Fig. 5A). Visits by X. bimaculata and Xylocopa sp4 were mostly or exclusively crepuscular, while Xylocopa sp1, Eulaema nigrita/Bombus pauloensis and Centris $\mathrm{sp} 1$ visits were primarily in the morning (08:00h-11:30h) (Fig. 5A). Oxaea sp was the only

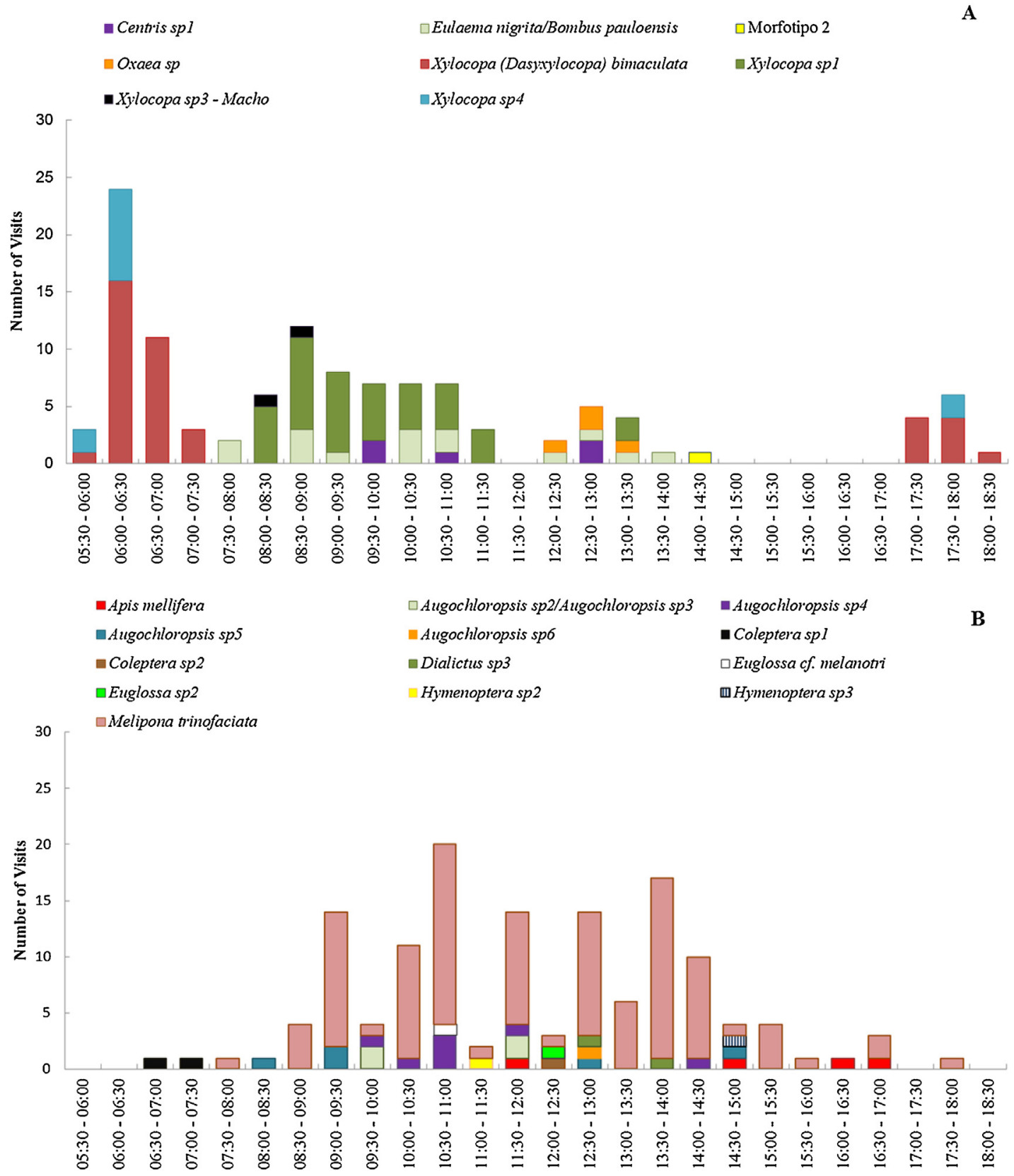

Fig. 5. Frequency of visits by (A) pollinators (principal and secondary) and (B) non-pollinating visitors (flower visitor and pollen theft) to flowers of Trembleya laniflora Cong. (Melastomataceae) at Serra do Cipó (Minas Gerais, Brazil). 
species of pollinator active in the afternoon (Fig. 5A). Among the species classified only as flower visitors, Melipona trinofaciata was the most frequent, with $78 \%$ of the visits (107), followed by Augochloropsis sp4 (7) and Augochloropsis sp5 (5) (Fig. 5B). Due to their small body size $(\leq 1.5 \mathrm{~cm})$ and behavior on the flowers, these three species were considered as pollen robbers or cheaters, not contributing to the reproduction of $T$. laniflora.

\section{Discussion}

The large, white flowers of $T$. laniflora did not conform to the expected characteristics of classic melittophily syndrome (flowers of often vibrant color and diurnal floral aperture; Faegri and Van der Pijl, 1979; Ollerton et al., 2009; Rosas-Guerrero et al., 2014). Instead, the T. laniflora flowers were open during the dawn and dusk hours and were mainly pollinated by bees with crepuscular foraging behavior. In Melastomataceae, white, cream or discrete flowers are generally small and typically associated with apomictic species that do not depend on pollination services to set fruits (Goldenberg and Sherpherd, 1998, Brito et al., unpublished data). Apomixis is a common feature in the family, occurring in up to $88 \%$ of the species in the tribe Miconieae (Renner, 1989; Goldenberg and Sherpherd, 1998; Santos et al., 2012). However, we did not consider T. laniflora as apomictic, since no fruits were formed after emasculation. The presence of large, white flowers was associated with anthesis at dawn and dusk and the pollination by crepuscular bees.

The absence of apomixis may be associated with the endemism and restricted occurrence of $T$. laniflora on rocky outcrops of campo rupestre in Minas Gerais (Martins, 1997; Santos et al., 2012). The relationship between the reproductive system of Melastomataceae and the geographic distribution of the species is a topic already described in the literature (Goldenberg and Sherpherd, 1998; Andrade et al., 2007; Santos et al., 2012). In general, apomictic species present a wider geographic distribution than those dependent on sexual reproduction, and the latter are frequently endemic or have restricted distribution (Goldenberg and Sherpherd, 1998; Santos et al., 2012). The high pollen viability, independent of the type of anther (feeding or pollination), observed in T. laniflora is also evidence of the species' investment in interbreeding (Goldenberg and Sherpherd, 1998; Santos, 2008).

The absence of germination and of viable embryos in the seeds from self-pollination experiments indicate that $T$. laniflora is selfincompatible and dependent on cross-pollination, even though the ISI values (equal to 1 ) have suggested self-compatibility, and the flower/fruit conversion rates of SP and CP treatments did not differ. The lack of fruit set or seeds by autonomous self-pollination reinforces the classification of $T$. laniflora as self-incompatible and dependent on interbreeding mediated by bees. The poricidal anthers and the dependence on vibration to release pollen prevent the occurrence of autogamy (self-pollination by pollen from the same flower) and favour the predominance of allogamy (interbreeding) in T. laniflora. The absence of autonomous selfpollination is a common characteristic of Melastomataceae, and it has been associated with the position of the anthers in relation to the stigma during anthesis (anthers stay coiled beneath the stigma from bud stage until flower opening) and with the necessity of vibration (buzz pollination) to remove pollen from the anthers (Renner, 1989; Goldenberg and Sherpherd, 1998). The dependence on pollinator-mediated interbreeding may promote genetic variability within the populations of endemic T. laniflora that occur naturally isolated on rocky outcrops, a topic to be explored in future research.

Trembleya laniflora was pollinated exclusively by large bees in the genera Xylocopa, Bombus, Eulaena and Centris, all capable of vibrating both circles of the poricidal anthers. Pollination occurred mainly during the highest availability of fresh, recently opened flowers in the crepuscular hours of the day. The crepuscular bees Xylocopa (Dasyxylocopa) bimaculata and Xylocopa sp4 contributed to $44 \%(\mathrm{~N}=52)$ of all observed pollination events, mostly during short periods of dim sunlight. Therefore, large bees with vibratory behavior and crepuscular foraging activity are the most effective pollinators of $T$. laniflora. The timing of floral opening and pollination were associated with the foraging behavior of those bees during the crepuscular hours of reduced light, an activity pattern known for some species of the families Apidae and Collectidae, especially from the genera Xylocopa, Centris and Ptiloglossa (Janzen, 1968; Wolda and Roubik, 1986).

Pollination by vibration (buzz pollination) is common in Melastomataceae (Renner, 1989; Harter et al., 2002; Brito and Sazima, 2012), and the evolutionary history of the family is associated with the vibratory behavior of bees (Vogel, 1978; Buchmann, 1983; Renner, 1989). Visits in periods of low light, during the minutes that precede the dawn, are reported for the species in the family (Frankie, 1976; Renner, 1989); nevertheless, the pollinators and their behavior are poorly described. With respect to the biology of bees with crepuscular foraging activity on flowers, knowledge is still scarce (Hopkins et al., 2000; Wcislo et al., 2004), and we are just starting to discover the importance of crepuscular vibratory bees for pollination.

The observed flowering and fruiting patterns have also been considered as adaptations of the species to effective pollination and to seed dispersal (Salazar et al., 2011; Silveira et al., 2012, Brito et al. unpublished data). Trembleya laniflora presents a large production of flowers and demonstrated highly seasonal flowering during the dry season and seed dispersal at the beginning of the rainy season. Flowering during the dry season is associated with the presence of pollinators and the highest rate of pollination by bees (Janzen, 1968). Reproduction during the dry season is described for subshrubby species of the family Melastomataceae of the sandy- and stony-soil meadows of Serra do Cipó (Le Stradic, 2012). The fruiting period corroborated previous descriptions of the species as presenting capsular, dehiscent fruits that open for the autochorous dispersal of seeds at the beginning of the rainy season (Silveira et al., 2012; Rodrigues and Silveira, 2013). In this period, the temperature and light conditions are the most adequate for seed germination and seedling development (Madeira and Fernandes, 1999; Silveira et al., 2012, Rodrigues and Silveira, 2013).

The high production of flowers, coupled with the differing quantities of immature and mature fruits produced, high percentages of embryoless seeds, and low germinability may be related to the frequent occurrence of abortions in Melastamataceae (Simão et al., 2007; Rodrigues and Silveira, 2013; Dayrell et al., 2016). Embryoless and non-viable seeds are a phylogenetically determined characteristic, frequent in Melastomataceae species of campo rupestre (Dayrell et al., 2016). Both characters are common in T. laniflora (Rodrigues and Silveira, 2013), and the occurrence of abortions in the family is related to occasional self-pollination events and malformation of the seeds, an outcome of nutritional deficiencies during development (Renner, 1989; Simão et al., 2007; Brito and Sazima, 2012; Rodrigues and Silveira, 2013). The campo rupestre presents highly P-deficient soils (Oliveira et al., 2015); therefore, the occurrence of embryoless and non-viable seeds in T. laniflora may also be associated with a P-limitation and consequent low investment in sexual reproduction and seed dispersal (Hopper, 2009; Fujita et al., 2014).

An additional hypothesis for the high investment in the formation of fruits with non-viable seeds would be the occurrence of inbreeding in the populations (Holmes et al., 2008; Dayrell et al., 2016). The dependence on interbreeding mediated by pollen vectors, coupled with seed dispersal over short distances by autochorous dispersal (Van Der Pijl, 1982) and the endemism of the 
species to rocky outcrops that are generally spatially isolated, may lead to endogamy. Thus, we suggest that the low production of viable embryos and the occurrence of frequent abortions are also consequences of a possible kinship mating between individuals and low genetic variability of the populations (Dubash and Fenster, 2000; Oostermeijer et al., 2003; Holmes et al., 2008).

Here, we demonstrated that $T$. laniflora presents a specialized buzz pollination system mediated by large crepuscular bees. We confirmed that the distinct floral characters (large, white-colored pollen flowers) and reproductive biology (nocturnal anthesis, selfincompatibility, large production of flowers) of $T$. laniflora are coupled with pollination by crepuscular bees. Therefore, although they differ from the classic pattern expected of melittophily species of Melastomataceae, the morphological characters (size and coloration) and flower biology (timing of anthesis) of T. laniflora are related to the behavior of its most effective pollinators. They are also consistent with the general "pollination syndromes" hypothesis of a direct relationship between a set of floral characters and the principal pollinating agent of the species (Faegri and Van der Pijl, 1979; Ollerton et al., 2009; Rosas-Guerrero et al., 2014).

The self-incompatibility of $T$. laniflora was confirmed only after the seed germination tests, and it is considered as a mechanism to avoid inbreeding and favour the occurrence of interbreeding in naturally isolated populations. The combined observations of flower biology, phenology, reproductive system, germination and pollination revealed the reproductive biology of this endemic species. Similar integrative studies of reproductive biology will improve our understanding of the ecology and evolution of native species and the dynamics of their populations. Such studies are especially relevant when considering endemic species that grow isolated in stressful environments such as the campo rupestre (Silveira et al., 2015).

\section{Acknowledgements}

We thank the many stakeholders who have allowed us to work on their lands and have offered logistical support: Vellozia Reserve, Environmental Protection Area Morro da Pedreira, Serra do Cipó National Park and the Cedro Company. We also thank D. W. Carstensen, F.A.O. Silveira, F.W. Amorim and G. W. Fernandes for their guidance and constant support; C. Schlindwein for identification of the bee species, and E. Giannotti and G. Locher for identification of the wasps. We are grateful also to André L. Giles, Annia S. Streher, Fabíula M. Arantes, Felipi C. Soares, Fernanda Hurbath, Jéssica G. Soares, Kauê F. Fernandes, M. Gabriela. G. Camargo, Maressa I. Valadares, Nathália. M. W. B. Rocha, Rafael L. Melo, Thaís M. Mesquita, and Vanessa C. Soares for assistance in the field; to Diego E. Escobar for your support with the seed germination tests; and to M. Gabriela G. Camargo and Irene Mendoza for valuable comments on the manuscript. This research was supported by São Paulo Research Foundation FAPESP (FAPESP-VALE-FAPEMIG grant \#2010/51307-0 and grant \#2013/50155-0 and grant \#2009/542086); Soares, N.C received fellowships from CAPES. Morellato, L.P.C. received $\mathrm{CNPq}$ research productivity fellowship.

\section{Appendix A.}

\section{Appendix B. Supplementary data}

Supplementary data associated with this article can be found, in the online version, at http://dx.doi.org/10.1016/j.flora.2016.12. 005.

\section{References}

Andrade, P.M.A., Forni-Martins, R.B., Martins, F.R.B., 2007. Reproductive system of Eriocnema fulva naudin (Melastomataceae), an endemic species of minas gerais state, SE, Brazil. Braz. J. Biol. 67, 313-319.

Athayde, E.A., Morellato, L.P.C., 2014. Anthropogenic edges, isolation and the flowering time and fruit set of Anadenanthera peregrine, a cerrado savanna tree. Int J. Biometeorol. 58, 443-454.

Ministério da Agricultura, Pecuária e Abastecimento Regras para Análise de Sementes (RAS), Brasília, 225-304.

Brito, V.L.G., Sazima, M., 2012. Tibouchina pulchra (Melastomataceae): reproductive biology of a tree species at two sites of an elevational gradient in the Atlantic rainforest in Brazil. Plant Syst. Evol. 298, 1271-1279.

Buchmann, S.L., 1983. Buzz pollination in angiosperms. In: Jones, C.E., Little, R.J (Eds.), Handbook of Experimental Pollination Biology. Van Nostrand Reinhold, New York, pp. 73-113.

Burgett, D.M., Sukumalanand, P., 2000. Flight activity of Xylocopa (Nyctomelitta) tranquebarica: a night flying carpenter bee (Hymenoptera: apidae). J. Apic. Res. 39, 75-83.

Clausing, G., Renner, S.S., 2001. Molecular phylogenetics of Melastomataceae and Memecylaceae: implications for character evolution. Am. J. Bot. 88, 486-498.

Conceição, A.A., Pirani, J.R., 2005. Delimitação de habitats em campos rupestres na Chapada Diamantina, Bahia: substratos: Composição florística e aspectos estruturais. Bol. Bot. Univ. São Paulo 23, 85-111.

Conceição, A.A., Pirani, J.R., 2007. Diversidade em quatro áreas de campos rupestres na Chapada Diamantina, Bahia, Brasil: espécies distintas mas riquezas similares. Rodriguésia 58, 193-206.

Dafni, A., Kevan, P.G., Husband, B.C., 2005. Practical Pollination Biology. Enviroquest. Ltd, Cambridge.

Dafni, A., 1992. Pollination Ecology: A Practical Approach. Oxford University Press, Oxford

Darwin, C., 1862. On the Various Contrivances by Which British and Foreign Orchids Are Fertilised by Insects and on the Good Effects of Intercrossing. John Murray, London.

Dayrell, R.L.C., Garcia, Q.S., Negreiros, D., Baskin, C.C., Baskin, J.M., Oliveira, F.A.O. 2016. Phylogeny strongly drives seed dormancy and quality in a climatically buffered hotspot for plant endemism. Ann. Bot., 1-11, http://dx.doi.org/10. 1093/aob/mcw163, Available online at: www.aob.oxfordjournals.org (Accessed 18 October 2016).

Dubash, M.R., Fenster, C.B., 2000. Inbreeding and outbreeding depression in fragmented populations. In: Young, A.G., Clarke, G.M. (Eds.), Genetics, Demography and Viability of Fragmented Population. Cambridge University Press, Cambridge, pp. 35-53.

Faegri, K., van Der Pijl, L., 1979. The Principles of Pollination Ecology, third ed. Pergamon Press, Oxford.

Fenster, C.B., Armbruster, W.S., Wilson, P., Dudash, M.R., Thomson, J.D., 2004 Pollination syndromes and floral specialization. Annu. Rev. Ecol. Syst. 35 375-403.

Franco, E.L., Gimenes, M., 2011. Pollination of Cambessedesia wurdackii in Brazilian campo rupestre vegetation, with special reference to crepuscular bees. J. Insect Sci. 11, 1-13.

Frankie, G.W., 1976. Pollination of widely dispersed trees by animals in Central America, with emphasis on bee pollination systems. In: Burley, J., Styles, B.T. (Eds.), Tropical Trees. Variation, Breeding and Conservation. Linnean Society Symposium. Academic Press, London, pp. 151-159.

Fujita, Y., Venterink, H.O., van Bodegrom, P.M., Douma, J.C., Heil, G.W., Hölzel, N., Jabłonska, E., Kotowski, W., Okruszko, T., Pawlikowski, P., de Ruiter, P.C., Wassenet, M.J., 2014. Low investment in sexual reproduction threatens plants adapted to phosphorus limitation. Nature 505, 82-86.

Giulietti, A.M., Menezes, N.L., Pirani, J.R., Meguro, M., Wanderley, M.G.L., 1987. Flora da Serra do Cipó, Minas Gerais: caracterização e lista de espécies. Bol. Bot. 9, 1-151.

Goldenberg, R., Sherpherd, G.J., 1998. Studies on the reproductive biology of Melastomataceae in cerrado vegetation. Plant Syst. Evol. 211, 13-29.

Goldenberg, R., Baumgratz, J.F.A., Souza, M.L.D.R., 2012. Taxonomia de Melastomataceae no Brasil: retrospectiva, perspectivas e chave de identificação para os gêneros. Rodriguésia 63, 145-161.

Harter, B., Leistikow, C., Wilms, W., Truylio, B., Engels, W., 2002. Bees collecting pollen from flowers with poricidal anthers in a south Brazilian Araucaria forest: a community study. J. Apic. Res. 40, 9-16.

Herrera, C.M., 1987. Components of pollinator quality: comparative analysis of a diverse insect assemblage. Oikos 50, 79-90.

Herrera, C.M., 1995. Microclimate and individual variation in pollinators: flowering plants are more than their flowers. Ecology 76, 1516-1524.

Herrera, C.M., 2005. Plant generalization on pollinators: species property or local phenomeon? Am. J. Bot. 92, 13-20.

Holmes, G.D., James, E.A., Hoffmann, A.A., 2008. Limitations to reproductive output and genetic rescue in populations of the rare shrub Grevillea repens (Proteaceae). Ann. Bot. 102, 1031-1041.

Hopkins, M.J.G., Fortune Hopkins, H.C., Sothers, C.A., 2000. Nocturnal pollination of Parkia velutina by Megalopta bees in Amazonia and its possible significance in the evolution of chiropterophily. J. Trop. Ecol. 16, 733-746.

Hopper, S.D., 2009. OCBIL theory: towards an integrated understanding of the evolution, ecology and conservation of biodiversity on old climatically buffered, infertile landscapes. Plant Soil 322, 49-86. 
Inouye, D., Gill, D., Dudash, M., Fenster, C., 1994. A Model and lexicon for pollen fate. Am. J. Bot. 81, 1517-1530.

Janzen, D.H., 1968. Notes on nesting and foraging behavior of Megalopta (Hymenoptera: halictidae) in Costa Rica. J. Kans. Entomol. Soc. 41, 342-350.

Köppen, W., 1931. Cimatologia. Fondo de Cultura Económica, Buenos Aires.

Labouriau, L.G., 1983. Capacidade e velocidade de germinação. In: Labouriau, L.G. (Ed.), A germinação das sementes. OEA, Washington, pp. 45-62.

Le Stradic, S., 2012. Composition, Phenology and Restoration of Campo Rupestre Mountain Grasslands-Brazil. PhD Thesis. Universidade Federal de Minas Gerais and Université d'Avignon et des Pays de Vaucluse, Belo Horizonte.

Levin, S.A., Muller-Landau, H.C., Nathan, R., Chave, J., 2003. The ecology and evolution of seed dispersal: a theoretical perspective. Ann. Rev. Ecol Evol. Syst. 34, 575-604.

Lunau, K., Papiorek, S., Eltz, T., Sazima, M., 2011. Avoidance of achromatic colours by bees provides a private niche for hummingbirds. J. Exp. Biol. 214, 1607-1612.

Lunau, K., Piorek, V., Krohn, O., Pacini, E., 2015. Just spines-mechanical defense of malvaceous pollen against collection by corbiculate bees. Apidologie 46, 144-149.

Madeira, J.A., Fernandes, G.W., 1999. Reproductive phenology of sympatric taxa of Chamaecrista (Leguminosae) in Serra do Cipó. J. Trop. Ecol. 15, 463-479.

Martins, E., 1997. Revisão taxonômica do gênero Trembleya (Melastomataceae). PhD Thesis. Universidade Estadual de Campinas, Campinas, SP.

Mendonça, R.C., Felfili, J.M., Walter, B.M.T., Silva, M.C.J.R., Rezende, A.V., Filgueiras, T.S., Nogueira, P.E., Fagg, C.W., 2008. Flora vascular do bioma Cerrado: checklist com 12.356 espécies. In: Sano, S.M., Almeida, S.P., Ribeiro, J.F. (Eds.), Cerrado: ecologia e flora. Embrapa, Cerrados, Brasília.

Morellato, L.P.C., Talora, D.C., Takahasi, A., Benck, C.C., Romera, E.C., Zipparro, V.B. 2000. Phenology of Atlantic rain forest trees: comparative study. Biotropica 32, 811-823.

Nunes-Silva, P., Hrncir, M., Imperatriz-Fonseca, V., 2010. A polinização por vibração. Oecol. Austr. 14,140-153.

Oliveira, R.S., Galvão, H.C., Campos, M.C.R., Eller, C.B., Pearse, S.J., Lambers, H., 2015 Mineral nutrition of campos rupestres plant species on contrasting nutrient-impoverished soil types. New Phytol. 205, 1183-1194.

Ollerton, J., Dafni, A., 2005. Functional floral morphology and phenology. In: Dafni, A., Kevan, P.G., Husband, B.C. (Eds.), Practical Pollination Biology. Enviroquest Ltd., Ontario, Canada, p. 590.

Ollerton, J., Lack, A.J., 1992. Flowering phenology: an example of relaxation of natural selection? Trends Ecol. Evol. 7, 274-276.

Ollerton, J., Alarcón, R., Waser, N.M., Price, M.V., Watts, S., Cranmer, L., Hingston, A., Peter, C.I., Rotenberry, J., 2009. A global test of the pollination syndrome hypothesis. Ann. Bot. 103, 1471-1480.

Oostermeijer, J.G.B., Luijten, S.H., Den Nijs, J.C.M., 2003. Integrating demographic and genetic approaches in plant conservation. Biol. Conserv. 113, 389-398.

Pinheiro, M., Gaglianone, M.C., Nunes, C.E.P., Sigrist, M.R., Santos, I.A., 2014. Polinização por abelhas. In: Rech, A.R., Agostini, K., Oliveira, P.E., Machado, I.C. (Eds.), Biologia da polinização. Projeto Cultural, Rio de Janeiro, pp. 205-233.

Pombal, E.C.P. Morellato, L.P.C., 2000. Differentiation of floral color and odor in two fly pollinated species of Metrodorea (Rutaceae) from Brazil. Plant Syst. Evol. 221, 141-156.

Queiroz, J.A., Quirino, Z.G.M., Machado, I.C., 2015. Floral traits driving reproductive isolation of two co-flowering taxa that share vertebrate pollinators. AoB Plants 7, 1-13.

R Development Core Team, 2011. R: A Language and Environment for Statistical Computing. R Foundation for Statistical Computing, Vienna, Austria.

Radford, A.E., Dickinson, W.C., Massey, J.R., Bell, C.R., 1974. Vascular Plant Systematics. Harper and Row Publishers Inc., New York.

Rapini, A., Ribeiro, P.L., Lambert, S., Pirani, J.R., 2008. A flora dos campos rupestres da Cadeia do Espinhaço. Megadiversidade 4, 16-24.
Renner, S.S., 1989. A survey of reproductive biology in Neotropical Melastomataceae and Memecylaceae. Ann. Mo. Bot. Gard. 76, 496-518.

Rocha, N.M.W.B., Carstensen, D.W., Fernandes, G.W., Le Stradic, S., Buisson, E., Morellato, L.P.C., 2016. Phenology patterns across a rupestrian grassland altitudinal gradient. In: Fernandes, G.W. (Ed.), Ecology and Conservation of Mountaintop Grasslands in Brazil. Springer, New York.

Rodrigues, E.R.S., Silveira, F.A.O., 2013. Seed germination requirements of Trembleya laniflora (Melastomataceae), an endemic species from neotropical montane rocky savannas. Plant Species Biol. 28, 165-168.

Rosas-Guerrero, V., Aguilar, R., Martén-Rodríguez, S., Ashworth, L., Lopezaraiza-Mikel, M., Bastida, J.M., Quesada, M., 2014. A quantitative review of pollination syndromes: do floral traits predict effective pollinators? Ecol. Lett. 17, 388-400.

Salazar, A., Goldstein, G., Franco, A.C., Miralles-Wilhelm, F., 2011. Timing of seed dispersal and dormancy rather than persistence in soil seed-banks, control recruitment of woody plants in Neotropical savannas. Seed Sci. Res. 21 $103-116$.

Santos, A.P.M., Fracasso, C.M., Santos, M.L., Romero, R., Sazima, M., Oliveira, P.E. 2012. Reproductive biology and species geographical distribution in the Melastomataceae: a survey based on New world taxa. Ann. Bot. 110, 667-679.

Santos, A.P.M., 2008. Biologia reprodutiva de Melastomataceae do Parque Nacional da Serra da Canastra, Minas Gerais. Master Thesis. Universidade Federal de Uberlândia, Uberlândia.

Silveira, F.A.O., Ribeiro, R.C., Oliveira, D.M.T., Fernandes, G.W., Lemos-Filho, J.P., 2012. Evolution of physiological dormancy multiple times in Melastomataceae from Neotropical montane vegetation. Seed Sci. Res. 22, 37-44.

Silveira, F.A.O., Santos, J.C., Franceschinelli, E.V., Morellato, L.P.C., Fernandes, G.W., 2015. Costs and benefits of reproducing under unfavorable conditions: an integrated view of ecological and physiological constraints in a cerrado shrub. Plant Ecol. 16, 963-974

Silveira, F.A.O., Negreiros, D., Barbosa, N.P.U., Buisson, E., Carmo, F.F., Carstensen, D.W., Conceição, A.A., Cornelissen, T.G., Echternacht, L., Fernandes, G.W., Garcia, Q.S., Guerra, T.J., Jacobi, C.M., Lemos-Filho, J.P., Le Stradic, S., Morellato, L.P.C., Neves, F.S., Oliveira, R.S., Schaefer, C.E., Viana, P.L., Lambers, H., 2016. Ecology and evolution of plant diversity in the endangered campo rupestre: a neglected conservation priority. Plant Soil 403, 129-152.

Simão, E., Nakamura, A.T., Takaki, M., 2007. Época de colheita e capacidade germinativa de sementes de Tibouchina mutabilis (Vell.) Cogn. (Melastomataceae). Biota Neotropica 7, 67-73.

Somanathan, H., Borges, R., 2001. Nocturnal pollination by the carpenter bee Xylocopa tenuisca (Apidae) and the effect of floral display on fruit set of Heterophragma quadriloculare (Bignoniaceae) in India. Biotropica 33, 78-89.

Van Der Pijl, L. Principles of dispersal in higher plants, 1982, New York.

Vogel, S., 1978. Evolutionary shifts from reward to deception in pollen flowers. In: Richards, A.J. (Ed.), The Pollination of Flowers by Insects. Academic Press, London.

Wcislo, W., Arneson, L., Roesch, K., Gonzalez, V., Smith, A., Fernández, H., 2004. The evolution of nocturnal behavior in sweat bees, Megalopta genalis and $M$. ecuadoria (Hymenoptera: halictidae): an escape from competitors and enemies? Biol. J. Linn. Soc. 83, 377-387.

Westerkamp, C., 1996. Pollen in bee-flower relations: some considerations on melittophily. Bot. Acta 109, 325-332.

Wolda, H., Roubik, D.W., 1986. Nocturnal bee abundance and seasonal bee activity in a Panamanian forest. Ecology 67, 426-433.

Zapata, T.R., Arroyo, M.T.K., 1978. Plant reproductive ecology of a secondary deciduous tropical forest in Venezuela. Biotropica 10, 221-230.

Zar, H.J., 1996. Biostatistical Analysis. Prentice-Hall, New Jersey. 